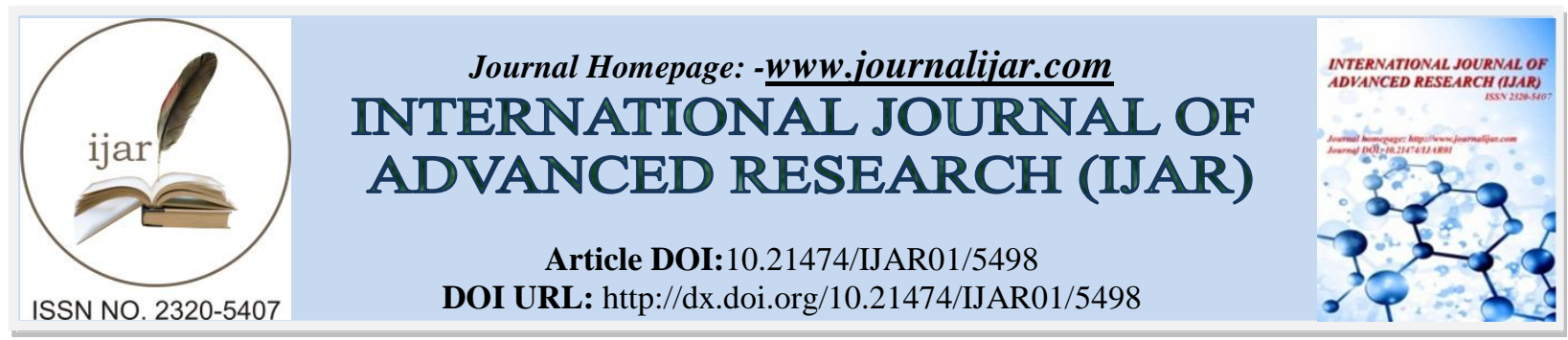

RESEARCH ARTICLE

\title{
FUTURE PROSPECTS OF INDIAN LEATHER INDUSTRY.
}

Dr. K. Thiripurasundari and C. Ponsakthisurya

Sri Parasakthi College for Women, Courtallam-627802.

\section{Manuscript Info}

Manuscript History

Received: 22 July 2017

Final Accepted: 24 August 2017

Published: September 2017

Keywords:-

Leather Industry, Export, Leather

Garments, Footwear, saddler and harness.

\section{Abstract}

Leather industries have a prominent place in India. It gives a more employment opportunity. Especially women employees are high. It plays a unique position in Indian Economy but the industries run profit motive and earn more profit through the leather product clusters like leather finished goods, leather garments leather footwear, saddler and harness. Tamilnadu has more leather cluster region like AmburVaniyambadi, Pernambut, Ranipet, Dindugul, Trichy. Theses cluster exports more leather products among other states of India. So India earn more annual turnover through leather industry because it has more region all over India and export more Leather products to all country. Hence, an attempt has been made in this paper to highlight "Future Prospects of Indian Leather Industry".

Copy Right, IJAR, 2017,. All rights reserved.

\section{Introduction:-}

The Indian Leather Industry occupies a unique position in the Indian economy. Leather is a durable and flexible material created by the tanning of animal rawhide and skin, often cattle hide. It can be produced through manufacturing processes ranging from cottage industry to heavy industry.

Leather is used for various purposes including clothing, bookbinding, leather wallpaper, and as a furniture covering. It is produced in a wide variety of types and styles and is decorated by a wide range of techniques.

The leather industry holds a prominent place in Indian economy in view of its massive potential for growth, providing employment opportunities to large number of artisans and also earns foreign exchange through exports. The major factors responsible for growth of Indian leather industry are the availability of raw materials (hides and skins), cheaper labour, technology and supportive government policies. The exports from the Indian leather sector earn Rs. 1, 06,910 million and provide direct employment to more than 2.5 million people from socially and economically backward communities. Women employment is predominant in leather products sector with about $30 \%$ share.

After china and Italy India ranks at the III ${ }^{\text {rd }}$ place amongst the Leather Production \& export Countries. This sector is known for its consistency in high export earnings and it is among the top ten foreign exchange earners for the country.

\section{Size of the Industry:-}

Indian leather industry has capacity to produce

1776 million pairs: 112 million pairs of Shoe 
Upper; Non - leather footwear - 960 million Pairs.

Geographical Distribution:-

Tamil Nadu:- Chennai, Ambur, Ranipet, Vaniyambadi, Trichy, Dindugul.

West Bengal:- Kolkata,

Uttar Pradesh:-Kanpur, Agra \& Noida

Maharashtra:-Mumbai; Punjab- Jallandhar;

Karnataka:- Bangalore;

Andhra Pradesh:-Hyderabad;

Haryana:-Ambala, Gurgaon, Panchkula and Karnal; Delhi.

Output per annum:-Has an annual turnover of approximately US\$ $\quad 50,00,000$.

Percentage in world market:-Indian Leather Industry currently is one among the top 8 industries for export revenue generation in India, holding $10 \%$ of global raw materials and $2 \%$ of global made.

Market Capitalization:-India produces approx 700 million pairs of leather footwear every year and accounts for an $18 \%$ share of the total Indian Leather export.Hence, an attempt has been made in this paper, to highlight the future prospects of Leather Industry in Industry in International business.

\section{Government Supportive Measures:-}

Some of the government initiatives to promote the Leather Industry include,

1. Leather sector is one of the "Focus Sectors" under Foreign Trade Policy of the Government of India.

2. Entire leather sector is de-licensed facilitating for expansion on modern lines with state of the art machinery and equipments. $100 \%$ foreign direct investment permitted through automatic route.

3. Import of specified machinery for use in leather and footwear industry allowed at a 5\% concessional import duty.

4. Duty free import of raw hides and skins, wet blue chrome tanned leather, crust leather and finished leather of all kinds including splits and sides thereof.

5. Duty free import of specified critical inputs for manufactures of leather garments and other leather products including footwear under duty free import scheme(DFIS)

6. Basic customs duty exempted on machinery or equipment for Effluent treatment plants in leather industry.

7. Gradual lowering of import tariff- current peak customs duty is $10 \%$

8. Simplified import/export procedures - quick customs clearances.

\section{Emerging strengths of Indian Leather Industry:-}

1. Design development initiatives by institutions and individuals

2. Continuous modernization and technology up gradation

3. Economic size of manufacturing units

4. Constant human resource development programme to enhance productivity

5. Increasing use of quality components

6. Shorter prototype development time

7. Delivery compliance

8. Growing domestic market for footwear and leather articles.

\section{The International Performance of Leather Industry:-}

1. Around $70 \%$ of the global trade in leather products in the Western Europe and North America, USA is the largest importer accounting for about $25 \%$ of the global trade. Germany is the $2^{\text {nd }}$ largest importer of leather products in the world.

2. Developing countries have become major suppliers of various leather products to the industrialized world. But the problem is with regard to the quality. The competition is now among developing countries themselves. 
3. Investments in India's leather Industry are flowing from countries like Italy, Spain, and Portugal through Joint ventures. Dereservation of the industry from the small scale sector may be contributing factors.

4. China is the largest exporter of leather with a global market share of $18 \%$ followed by Italy and Germany.

5. The Chinese leather Industry has been able to meet demand in expensive alternative in major way. Hence, some of leading leather goods manufactures in India have opted for importing cheaper skin from china, and do processing and finishing work at facilities in India, before exporting to western markets.

6. Compared to India's share of less than $3 \%$ in the international leather export trade china's share is a massive $55 \%$. India still has a long way to export with china (exports $\$ 18$ billion) or even smaller countries Italy whose exports amounted to $\$ 12$ billion.

7. Although the US was the world's largest importer of leather goods, only $11.7 \%$ of Indian leather exports could penetrate that market. Of course, India has nearly $60 \%$ share in the high - end leather garments export business.

8. India's export of Leather and Leather Products increased from Euro 1618.01 Million.

Table-1

\begin{tabular}{|l|c|c|c|c|c|c|c|c|c|}
\hline \multicolumn{10}{|c|}{ India's Export of Leather and Leather Products During 2005- 06 to 2013 -14 } \\
In Million US\$
\end{tabular}

The above table presents the segments of leather and leather product export. In the year 2006-07, total finished leather, footwear, leather goods, saddler \& harness, and leather garment's growth was $11.15 \%$. In the following years the growth increased to $15.99 \%, 1.44 \%$. But in the year $2009-10$ the growth percentages came down to $5.51 \%$. In the year 2010-11, the growth again increased and in the following years the growth steadily increased. But 2012-13, the growth again decreased as 2.91\%. In the year 2013-14 growth percent increased again in the coming years $\%$ of growth came down due to low production or lower level of export quantity.

\section{Future outlook:-}

The future outlook of the leather production and exports are expected to be really promising. The futures production and export outlook have been worked out assuming rate of growth for finished leather, footwear, and other leather products. The results are presented in the following table

Table - 2

\begin{tabular}{|l|r|r|r|r|r|r|}
\hline \multicolumn{7}{|c|}{ India's export 2000, 2010 } \\
\hline \multicolumn{7}{|c|}{ and 2020 share of Leather product segments } \\
\hline \multicolumn{1}{|c|}{ Product } & $\mathbf{2 0 0 0}$ & \% share & \multicolumn{1}{c|}{$\mathbf{2 0 1 0}$} & \% share & $* \mathbf{2 0 2 0}$ & \multicolumn{1}{c|}{ \% share } \\
\hline Leather & 381.49 & $19.43 \%$ & 625.54 & $18.39 \%$ & 899.64 & $9.18 \%$ \\
\hline Footwear & 638.57 & $32.52 \%$ & 1507.51 & $44.32 \%$ & 5760.44 & $58.78 \%$ \\
\hline Leather Garments & 460.45 & $23.45 \%$ & 428.52 & $12.60 \%$ & 965.30 & $9.85 \%$ \\
\hline Leather Goods & 440.37 & $22.43 \%$ & 756.02 & $22.23 \%$ & 1900.22 & $19.39 \%$ \\
\hline
\end{tabular}




\begin{tabular}{|l|r|r|r|r|r|r|}
\hline \&Accessories & & & & & \\
\hline Saddlery\& Harness & 42.66 & $2.17 \%$ & 83.39 & $2.46 \%$ & 274.40 & $2.80 \%$ \\
\hline Total & $\mathbf{1 9 6 3 . 5 5}$ & $\mathbf{1 0 0 . 0 0 \%}$ & $\mathbf{3 4 0 0 . 9 8}$ & $\mathbf{1 0 0 \%}$ & $\mathbf{9 8 0 0 . 0 0}$ & $\mathbf{1 0 0 . 0 0}$ \\
\hline
\end{tabular}

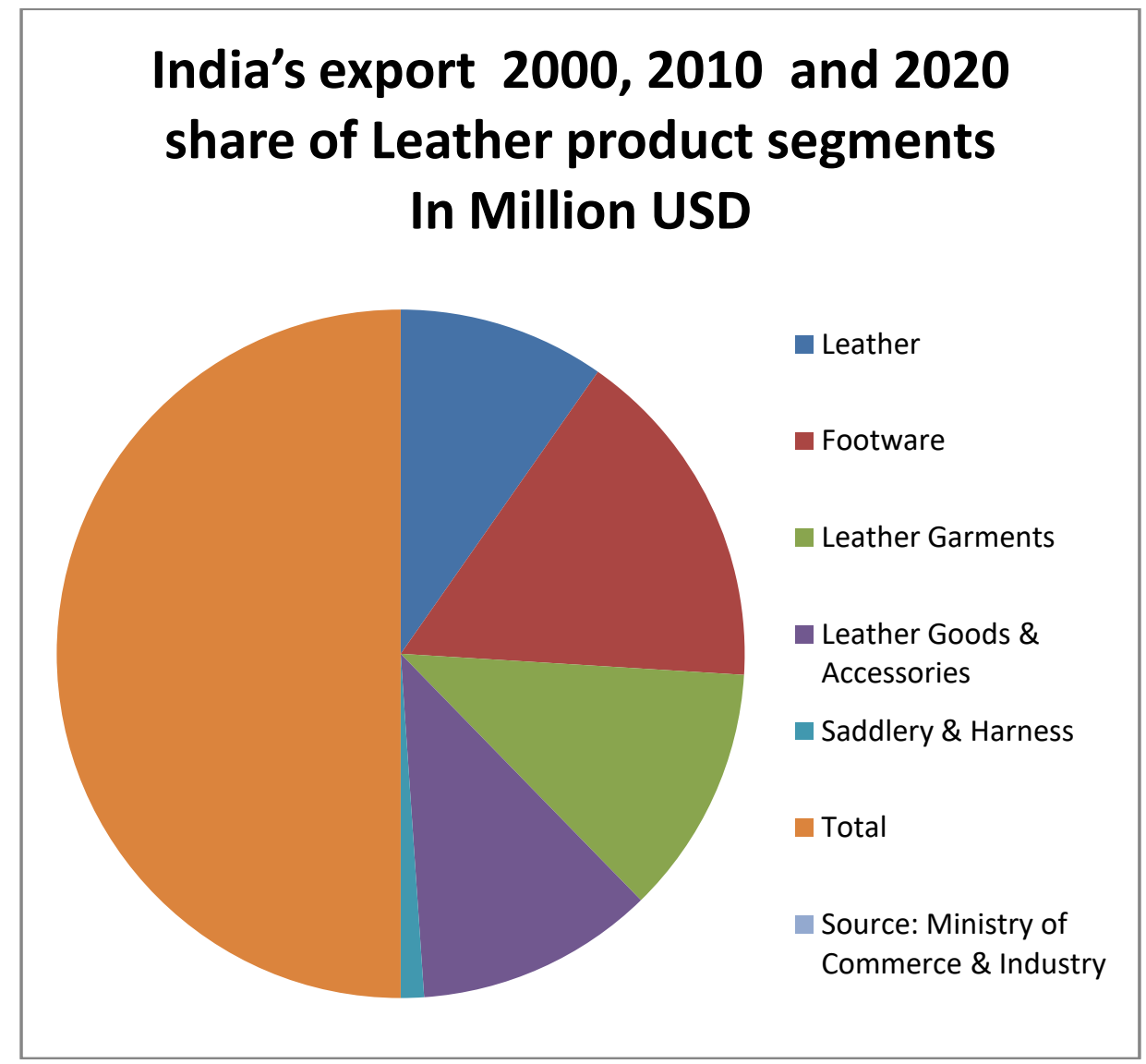

2020

1. Footwear will constitute about $60 \%$ of export

2. Second important segment is going to be Leather Goods

3. Share of leather \& leather garments will be less that $10 \%$ each of Leather Products.

The following table reflects India's export participation in leather products such as leather goods finished leather, leather garments saddler $\&$ harness etc.

Table-3

\begin{tabular}{|c|c|c|c|c|c|}
\hline \multicolumn{6}{|c|}{$\begin{array}{l}\text { India's export } 2010 \\
\text { and } 2020 \text { (\% growth) }\end{array}$} \\
\hline \multicolumn{6}{|r|}{ In Million USD } \\
\hline Product & 2000 & 2010 & $\begin{array}{l}\text { \% growth in } 2010 \\
\text { over } 2000\end{array}$ & *2020 & $\begin{array}{c}\text { \% growth in } 2020 \\
\text { over } 2010\end{array}$ \\
\hline Leather & 381.49 & 625.54 & $63.97 \%$ & 899.64 & $9.18 \%$ \\
\hline Footwear & 638.57 & 1507.51 & $136.08 \%$ & 5760.44 & $58.78 \%$ \\
\hline Leather Garments & 460.45 & 428.52 & $-6.93 \%$ & 965.30 & $9.85 \%$ \\
\hline $\begin{array}{l}\text { Leather Goods \& } \\
\text { Accessories }\end{array}$ & 440.37 & 756.02 & $71.68 \%$ & 1900.22 & $19.39 \%$ \\
\hline Saddlery\& Harness & 42.66 & 83.39 & $95.48 \%$ & 274.40 & $2.80 \%$ \\
\hline Total & 1963.55 & 3400.98 & $73.21 \%$ & 9800.00 & 100.00 \\
\hline
\end{tabular}




\section{Source: Ministry of Commerce \& Industry}

*Projection

1. Footwear will be the engine of growth for the leather sector $-282 \%$ growth by the year 2020 over 2010

2. Leather Garments is expected to recapture the growth.

\section{Challenges facing the Leather Industry way forward:-}

\section{Raw Material:-}

1. Need to enhance availability.

2. Technology.

3. Design \& creativity.

\section{Human Resource Development:-}

1. Training of skilled work force.

2. Competition with hi - tech industries in attracting.

3. Retaining the labour force.

4. Attracting high quality professionals.

\section{Environment:-}

1. Living in harmony.

2. Reverse osmosis plants, zero liquid discharge technology.

3. Health and safety Regulations. REACH (Registration Evaluation Authorization and Restriction of Chemicals ), US law on Lead Content etc,

\section{Infrastructure:-}

1. Expansion of production capacities.

2. Economies of scale.

\section{Capital:-}

1. Attracting public equity.

\section{Volume Business:-}

1. Growth of luxury Brands.

2. Huge consumer demand.

\section{Conclusion:-}

This paper highlights the growing opportunities available to leather industry in India. Leather products like hand bags, footwear and leather garments have the largest export growth potentials in the leather industry. On the export front, the industry is able to make satisfactory progress. Joint ventures and FDI would give a boost to the Indian leather Industry. It has been able to handle global development with confidence. The support extended by the government has proved to be valuable. In the coming years the future outlook for the Indian Leather Industry seems to be positive.

\section{References:-}

Journals:-

1. Monthly Abstract of Statistics, Vol no: 58, No.4 April 2005.

2. Business and Economics- Facts for you, Vol no: 27, No: 5 June 2007.

3. The Hindu Survey of Indian Industry, Vol no: 5, 2010.

4. Business and Economics- Facts for you, Vol no: 27, No: 7 June 2012.

\section{Websites:-}

1. $\quad$ www.clri.org Accessed on Jan 2017.

2. www.leatherindia.org, Accessed on May 2017.

3. www.cle.com, Accessed on sep.2017. 